\title{
Stress kinases in the modulation of metabolism and energy balance
}

\author{
Elisa Manieri ${ }^{1,2}$ and Guadalupe Sabio ${ }^{1}$ \\ ${ }^{1}$ Myocardial Pathophysiology Area, Fundación Centro Nacional de Investigaciones Cardiovasculares Carlos III, CNIC, \\ C/Melchor Fernandez Almagro, 2, 28029 Madrid, Spain \\ ${ }^{2}$ Department of Immunology and Oncology, Centro Nacional de Biotecnología/CSIC, Campus de Cantoblanco, \\ Madrid, Spain
}

Correspondence should be addressed to $\mathrm{G}$ Sabio Email gsabio@cnic.es

\begin{abstract}
Obesity is a new global pandemic, with growing incidence and prevalence. This disease is associated with increased risk of several pathologies, including diabetes, cardiovascular diseases, and cancer. The mechanisms underlying obesity-associated metabolic changes are the focus of efforts to identify new therapies. Stress-activated protein kinases (SAPK), including cJun N-terminal kinases (JNKs) and p38, are required for cellular responses to metabolic stress and therefore might contribute to the pathogenesis of obesity. Tissue-specific knockout models support a cell-type-specific role for JNK isoforms, in particular JNK1, highlighting its importance in cell homeostasis and organ crosstalk. However, more efforts are needed to elucidate the specific roles of other JNK isoforms and p38 family members in metabolism and obesity. This review provides an overview of the role of SAPKs in the regulation of metabolism.
\end{abstract} Key Words $\checkmark$ JNK

$-\mathrm{p} 38$

- SAPK

- metabolism

- obesity

- stress

- adipose tissue

- brain and signal transduction

\section{Introduction}

The totality of biochemical reactions that a cell requires to grow, survive and respond to external stimuli is known as metabolism. These processes are classified into two interdependent groups. Catabolism is the set of reactions that break down complex molecules to produce energy. This process produces NADH or ATP, which are required to synthesize macromolecules such as proteins, lipids and nucleic acids. This set of synthetic reactions is known as anabolism. Anabolism and catabolism play opposing roles in the maintenance of cell functions, but these processes are tightly coordinated in order to preserve cell homeostasis. Endocrine hormones, such as insulin, finely regulate the molecular pathways involved in the activation of anabolic and catabolic enzymes. Whenever this coordinated regulation is lost, anabolism and catabolism become unbalanced, giving rise to metabolic disorders.
Obesity, the most common metabolic disorder worldwide, develops when energy intake exceeds energy expenditure (Speakman 2010). Obesity is a major cause of morbidity and mortality, and is associated with increased risk of type 2 diabetes mellitus, heart disease, metabolic syndrome, hypertension, stroke, and certain forms of cancer (Haslam \& James 2005). The design of new treatments requires knowledge of the diverse molecular mechanisms that contribute to obesity and its associated diseases.

MAPK signalling cascades transduce a variety of extracellular signals that regulate cellular responses (Sabio \& Davis 2014). Three groups of MAPKs have been identified: the ERK, the p38 MAPKs, and the cJun N-terminal kinases (JNK). ERKs are mainly activated by mitogens and differentiation signals, JNK and p38 MAPK are activated by stress stimuli and are

Published by Bioscientifica Ltd 


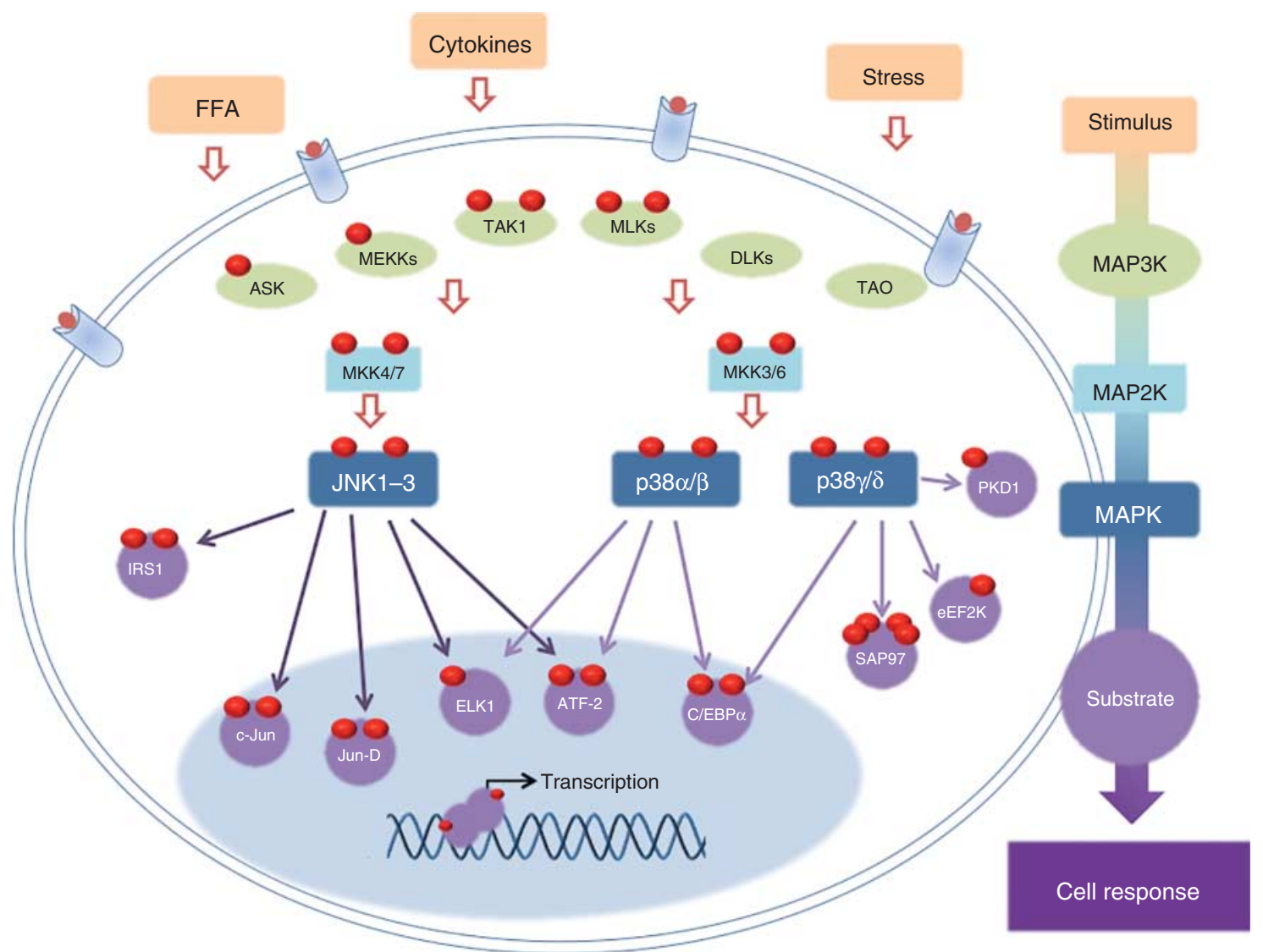

\section{Figure 1}

Stress-activated protein kinase signaling pathway. Like all MAPK family members, the SAPKs, JNKs and p38s, are activated by a phosphorylation cascade. SAPKs are activated by stimuli such as cytokines and free fatty

collectively named stress-activated protein kinases (SAPK) (Fig. 1) (Sabio \& Davis 2014). The SAPK family is composed of the four isoforms of p38 (p38 alpha, beta, gamma and delta) and the three isoforms of JNK (JNK1, 2, and 3) (Paul et al. 1997). While the JNK pathway has been extensively studied and JNK1 has been implicated in the development of obesity and insulin resistance (Sabio \& Davis 2010), the role of p38 MAPKs in this context has received less attention. Obesity results in a low-grade inflammation state (Neels \& Olefsky 2006), with increased levels of proinflammatory cytokines such as tumour necrosis factor alpha (TNF $\alpha$ ) and interleukin 6 (IL6) and of circulating free fatty acids (FFA), causing the activation of stress-induced mechanisms in the cell (Hotamisligil 2006).

\section{cJun N-terminal kinases}

Three genes encode the members of JNK family. While $J n k 1$ and $J n k 2$ are ubiquitously expressed, $J n k 3$ is acids, which are abundant in the obese state. Activation culminates with the phosphorylation of specific target proteins, inducing the appropriate cell response depending on the cell stimulus.

specifically expressed in brain, testis and heart (Davis 2000, Chang \& Karin 2001). Each JNK member can be expressed in several splice variants, which can be separated in two groups based on their size: the short forms of about $46 \mathrm{kDa}$ (JNK1 $\alpha 1$, JNK1 $\beta 1$, JNK2 $\alpha 1$ JNK2 $\beta 1$ JNK3 $\alpha 1$ ) and the long forms of about 54 KDa (JNK1 $\alpha 2$, JNK1ß2, JNK2 $\alpha 2$ JNK2ß2 JNK3 $\alpha 2$ ) (Gupta et al. 1996, $\mathrm{Yu}$ et al. 2004). Many cells types express at least four JNK splice variants, with JNK1 variants predominating over JNK2 variants among the short forms and the reverse pattern observed for the long forms (Gupta et al. 1996, Yu et al. 2004). The function and the exact modulation of each of these splice variants is still unsolved.

JNKs are activated in response to a wide range of stimuli, such as cytokines (IL6, TNF $\alpha$ ), environmental stresses (hypoxia, u.v. and ionizing radiation), toxins, drugs and metabolic changes, including obesity and hyperlipidaemia. JNKs are directly activated by two upstream MAP kinase kinase (MAP2K) enzymes, MKK4

Published by Bioscientifica Ltd. 
and MKK7, through a dual phosphorylation on tyrosine and threonine in the conserved Thr-Pro-Tyr motif in their activation loop (Paul et al. 1997). The more than 50 proteins identified as JNK substrates include c-Jun, which once phosphorylated can dimerize with JunB, JunD or c-Fos to form the transcription factor activator protein-1 (AP-1) (Hotamisligil et al. 1996a); insulin receptor substrate 1 (IRS1) (Kim et al. 2004b); c-myc; p53, and numerous transcription factors (Davis 2000, Chang \& Karin 2001, Bogoyevitch \& Kobe 2006). Through the phosphorylation of their targets, JNKs induce a specific cell response to the specific stimulus, characterized by apoptosis, cell proliferation, and cell migration.

Despite its importance for brain function (Pirianov et al. 2007, Yoon et al. 2012), the JNK3 isoform as yet has no demonstrated role in metabolism. In contrast, a large body of literature attests to the key roles of JNK1 and JNK2 isoforms as regulators during obesity-induced inflammation and metabolic disorders (Tuncman et al. 2006,
Singh et al. 2009, Czaja 2010, Han et al. 2013). The JNK pathway is strongly activated in liver, adipose tissue and muscle during dietary and genetically-induced obesity (Hirosumi et al. 2002). Hirosumi et al. (2002) showed that mice with whole-body knockout of JNK1, but not JNK2, are protected against obesity and insulin. This finding correlates with a reduced total JNK activation in JNK1 knockout, whereas JNK2 knockout mice do not show this effect. Moreover, JNK1 knockout mice gain less weight (Hirosumi et al. 2002) and are resistant to liver steatosis induced by a diet deficient in methionine and choline (Schattenberg et al. 2006). Here, we provide an overview of the roles of JNK1 and JNK2 in metabolism and metabolic disorders (Fig. 2).

\section{Liver}

In mammals, the liver plays an essential role in metabolism, and is central to the maintenance of glucose

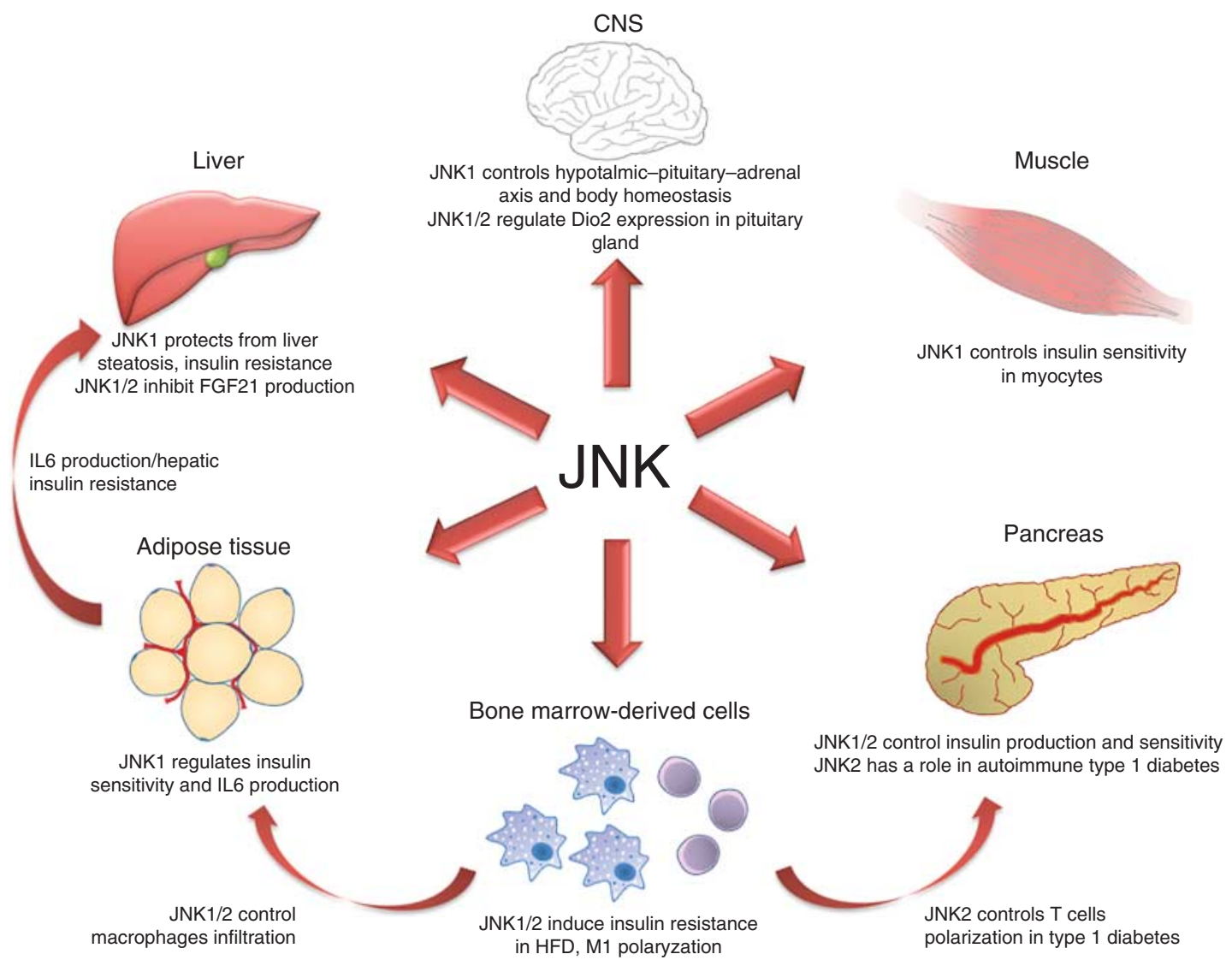

Figure 2

Organ-specific roles of JNK isoforms in metabolism. JNK proteins play a pivotal role in metabolism. Functions of JNK1 and JNK2 are organ- and cell-specific, and have been extensively studied in tissue-specific knockout mouse models. 
and lipid homeostasis in the body. Hepatic insulin resistance and non-alcoholic fatty liver disease (NAFLD) are the most frequent liver consequences of the obese state. Using adenoviruses to overexpress or downregulate JNK, Nakatani et al. (2004) defined a central role for the hepatic JNK pathway in determining whole-body insulin sensitivity. These authors showed that hepatic overexpression of WT JNK induces insulin resistance in non-diabetic mice, whereas suppression of the JNK pathway in liver ameliorated insulin resistance in genetically obese mice (Nakatani et al. 2004). Moreover, studies in whole-body JNK1-knockout mice have shown that this kinase controls lipid accumulation and lipid uptake in liver (Imbernon et al. 2013). These findings indicate that the role of JNKs isoforms can differ between cell types. In fact, the phenotype of whole-body JNK1-knockout mice (Hirosumi et al. 2002) and adenovirus-treated mice (Nakatani et al. 2004) could be due to the ablation of JNK1 in parenchymal cells or extra hepatic tissues, highlighting the importance of cell and organ crosstalk. Hepatocyte-specific deletion of JNK1 provided further information about its role in liver steatosis and insulin resistance during obesity. Intriguingly, these mice displayed increased insulin resistance, glucose intolerance and hepatic steatosis, showing that JNK1 plays a protective role in hepatocytes (Sabio et al. 2009). In contrast, hepatocyte-specific simultaneous knockout of JNK1 and JNK2 induces systemic protection against high fat diet (HFD)-induced insulin resistance (Vernia et al. 2014). Vernia et al. demonstrated that JNK could indirectly inhibit the activity of the nuclear peroxisome proliferatoractivated receptor alpha (PPAR $\alpha$ ), thus preventing production of fibroblast growth factor 21 (FGF21). FGF21 plays a pivotal role in control ketogenesis, insulin sensitivity, glycaemia and obesity. In consequence, they found that lack of JNK1/2 in hepatocytes protects against obesity-induced diabetes (Vernia et al. 2014). JNK1 modulates liver insulin resistance and steatosis through two distinct molecular actions. On one hand, JNK1, upon activation by proinflammatory cytokines (e.g. TNF $\alpha$ ) and circulating FFAs, phosphorylates the IRS1 on serine 307 , preventing its interaction with the insulin receptor. This blocks insulin cellular signalling, inducing insulin resistance (Hotamisligil et al. 1996b, Aguirre et al. 2000). On the other hand, JNK1 is necessary in hepatocytes for the homeostatic maintenance of gluconeogenesis and lipogenesis and the prevention of hepatic insulin clearance due to the elevated expression of insulin receptor in this cell type (Sabio et al. 2009).

\section{Adipose tissue}

The most important organ for lipid storage is adipose tissue, the only tissue with high capacity to expand in a non-transformed state. However, adipocytes are not merely fat storage cells, in fact play a central role in metabolism and organismal homeostasis through the secretion of adipokines (Gavrilova et al. 2000). In the obese state, adipocyte enlargement induces molecular and cellular alterations that affect whole-body metabolic homeostasis. Increased lipolysis in adipocytes leads to increased hyperlipidaemia and lipid accumulation in peripheral organs, in particular muscle and liver. Moreover, adipocytes begin to produce a number of proinflammatory cytokines, such as IL6, TNF $\alpha$, monocytechemoattractant protein-1 (MCP-1), inducible isoform nitric oxide synthase (iNOS), transforming growth factor-beta1 (TGF- $\beta 1$ ), and plasminogen activator inhibitor-1 (PAI-1) (Hotamisligil et al. 1993). Obese adipose tissue also recruits macrophages that contribute to the generation of a chronic inflammation state and insulin resistance (Weisberg et al. 2003, Xu et al. 2003). Adipocytes are thus target of stress stimuli during obesity, and, as mentioned previously, genetically- and dietaryinduced obesity both activate JNK in adipose tissue (Hirosumi et al. 2002). The scaffold protein JNK interacting protein 1 (JIP1) has been shown to play a central role in JNK activation in adipose tissue (Jaeschke et al. 2004). $\mathrm{JIP} 1^{-1-}$ mice are resistant to diet-induced obesity and show less severe insulin resistance. JNK cannot be activated in the adipose tissue and muscle of JIP1 ${ }^{-1-}$ mice, preventing the acquisition of insulin resistance in those tissues. However, the livers of JIP1 ${ }^{-1-}$ mice have no defect in JNK activation, which may account for the incomplete protection against insulin resistance in these animals. This demonstrates that adipose tissue protection from insulin resistance is cell specific and it is not due to a whole body protection from obesity (Jaeschke et al. 2004). Mice with adipocyte-specific JNK1-deficiency have been used to analyse the role of JNK1 in adipose tissue (Sabio et al. 2008). When fed a high-fat diet, these mice show a similar body-mass gain to their control counterparts. However, the adipocyte JNK1-knockout mice are protected against insulin resistance in adipose tissue. This phenotype could be due to the absence of JNK1-mediated inhibitory phosphorylation of IRS1. Surprisingly, knockout of JNK1 in adipose tissue also induces protection against insulin resistance in liver (Sabio et al. 2008). Adipose JNK1-knockout mice exhibit a strong reduction in adipose tissue production of IL6, reflected in decreased

Published by Bioscientifica Ltd 
levels of circulating IL6. This proinflammatory cytokine is known to induce hepatic insulin resistance (Klover et al. 2003, Kim et al. 2004a). In conclusion, JNK1 in adipose tissue regulates local insulin sensitivity through IRS1 phosphorylation and also controls adipocyte-IL6 production and adipocyte crosstalk with other organs. In the obese state, adipose JNK1 induces hepatic insulin resistance through IL6 production (Sabio et al. 2008).

\section{Bone-marrow-derived cells}

Obesity induces a low-grade chronic inflammation that could be partly responsible for the observed metabolic changes (Hotamisligil 2006, Neels \& Olefsky 2006). Increasing food intake increases adipose tissue fat storage, which induces adipocyte enlargement, hypoxia, stress, cell death, and proinflammatory cytokine production. These changes have been proposed to induce immune-cell recruitment to adipose tissue and produce a chronic activation of the immune response (Ferrante 2013). However, how fat deposition in adipose tissue activates the immune system is not completely understood. The obese state also induces immune activation in organresident macrophages, in particular Kupffer cells in the liver, probably inducing insulin resistance (Lanthier et al. 2010). In order to assess the role of JNK in the immune system in obesity and obesity-induced disorders, several studies have examined mice lacking JNK proteins in myeloid or bone-marrow-derived specific knock out mice. Zhang et al. (2011) examined the effect of a highfat diet on transgenic mice overexpressing dominantnegative JNK in adipose tissue and macrophages. These mice showed reduced weight gain, insulin resistance, glucose intolerance and hepatic steatosis. Moreover, these mice had smaller-than-normal adipocytes, reduced macrophage infiltration in adipose tissue, and less-severe whole-body inflammation (Zhang et al. 2011). The authors concluded that JNK isoforms are responsible for the crosstalk between adipose tissue and macrophage infiltration, and showed that abrogation of their expression in both cell types is necessary to obtain the same phenotype seen in JNK1 full body knock out mice (Zhang et al. 2011). However, these results do not fully elucidate the role of JNK proteins expressed in hematopoietic cells. Solinas et al. (2007) used adoptive transfer to demonstrate that JNK1 deletion in non-hematopoietic tissues protects against weight gain and, partly as a consequence, from insulin resistance. Moreover, they showed that hematopoietic JNK1 removal reduces obesity-induced inflammation and protects against HFD-induced insulin resistance without affecting obesity (Solinas et al. 2007). However, another group reported that JNK1-deficient bone marrow transplantation was not sufficient to induce protection against insulin resistance and macrophage infiltration of adipose tissue in a WT recipient, whereas this protection was induced by the absence of JNK1 in parenchymal cells (Vallerie et al. 2008). Taken together, these results highlight the importance of understanding the role of JNK2 in the myeloid lineage. To address this question, the Davis laboratory generated a myeloid-cellspecific knockout mouse model for JNK1 and JNK2 (Han et al. 2013). When fed a HFD, these mice show the same obesity and hyperlipidaemia responses as WT controls, but are more insulin sensitive (Han et al. 2013). The myeloid JNK1/2-knockout mice also show less macrophage infiltration and decreased M1 polarization in adipose tissue. M1 polarization was also decreased in hepatic macrophages, accompanied by increased M2 polarization, highlighting an important role for JNK in M1 polarization. In vitro experiments further confirmed an intrinsic defect in M1 polarization (Han et al. 2013). Finally, a role has been described for JNK2 in T cells in type 1 diabetes (Jaeschke et al. 2005). Non-obese diabetic (NOD) mice lacking JNK2 exhibit a decrease in spontaneous diabetes and insulitis, probably due to increased Th2 polarization of CD4+T cells (Jaeschke et al. 2005). The authors of this study reported that this T-cell polarization effect was not seen in JNK1 ${ }^{-1-}$ NOD mice, indicating a specific role for JNK2 in the regulation of T-cell polarization (Jaeschke et al. 2005).

\section{Skeletal muscle}

Skeletal muscle is a very large organ that requires abundant available energy to carry out its functions. Myocytes therefore play a major role in insulin-induced glucose disposal and are sensitive to obesity-induced insulin resistance. Evidence suggests that circulating FFAs, whose levels are increased in obesity, might be responsible for skeletal muscle insulin resistance (Shulman 2000, Roden 2004). FFAs induce the phosphorylation cascade that activates JNKs, suggesting a possible a role for JNKs in skeletal muscle insulin resistance. Moreover, JNK1 is activated in muscle from HFD-fed mice (Hirosumi et al. 2002). Muscle-specific JNK1-knockout mice reveal a role for this isoform in the induction of insulin resistance in skeletal muscle fed a HFD (Sabio et al. 2010a). These mice are sensitive to HFDinduced obesity. However, they are protected against obesity-induced insulin resistance and show increased glucose uptake by muscle, probably as result of a reduction

Published by Bioscientifica Ltd. 
in IRS1 serine phosphorylation. Surprisingly, adipose tissue and liver are not positively affected by JNK1 deficiency in skeletal muscle (Sabio et al. 2010a). Instead, these mice show increased hepatic steatosis and circulating levels of triglycerides, due to a reduction in lipoprotein lipase $(L p l)$ gene expression in muscle. Moreover, the augmented blood levels of triglycerides induce an increase in adipose tissue macrophage infiltration (Sabio et al. 2010a). Interestingly, inhibiting JNK in muscle by overexpressing heat shock protein 72 (HSP72) improves HFD-induced hyperglycaemia and hyperlipidaemia (Chung et al. 2008). Moreover, it prevents glucose intolerance and insulin resistance, and reduces HFDinduced weight gain (Chung et al. 2008). Taken together, these results indicate that lack of JNK1 expression in muscle modulates insulin sensitivity in a cell-autonomous manner but does not influence insulin sensitivity in other tissues (Sabio et al. 2010a). However, inhibiting total JNK activity in muscle can ameliorate the whole-body response to HFD (Chung et al. 2008). It would be interesting to study the effect of JNK2 deficiency in muscle to identify its possible role in tissue crosstalk.

\section{Pancreatic $\beta$ cells}

Insulin is produced by $\beta$ cells in the pancreatic islets of Langerhans. In a healthy state, $\beta$ cells, which make up $65-80 \%$ of the cells in the islet, respond to increases in serum glucose by secreting insulin, which induces glucose uptake in peripheral organs. Chronic hyperglycaemia induces changes in $\beta$-cell gene expression that lead to cell hypertrophy and loss of differentiation (Jonas et al. 1999). Glucose-induced insulin gene expression is also inhibited by saturated fatty acids (which are increased in obesity) through the activation of JNK in $\beta$ cells, resulting in the phosphorylation and inhibition of IRS1 and IRS2 (Solinas et al. 2006). Moreover, overexpression experiments have shown that activation of JNK by oxidative stress leads to $\beta$-cell failure (Kaneto et al. 2002, 2005). JNKinteracting protein 1 , a scaffold protein that regulates JNK activity (Whitmarsh et al. 2001), has been identified as a potential regulator of type 2 diabetes in humans (Waeber et al. 2000) and has been shown to mediate $\beta$-cell apoptosis (Haefliger et al. 2003). Despite these results, experiments in animals lacking JIP1/JIP2 protein indicate that these proteins are not essential for $\beta$-cell viability (Standen $e t a l$. 2009). Activation of JNK in $\beta$ cells by overexpression of constitutively active MKK7 results in impaired insulin production (Lanuza-Masdeu et al. 2013), a result consistent with previous work showing that $\mathrm{JNK}^{-1-} \beta$ cells in non-obese mice are protected against apoptosis induced by $\mathrm{T}$ cells in a model of autoimmune type 1 diabetes (Jaeschke et al. 2005). All these results indicate a specific role of JNK in $\beta$ cells as a regulator of insulin production and secretion, and prolonged JNK activation, as in the obese state, can induce islet dysfunction.

\section{CNS}

In the CNS, the onset of hypothalamic resistance to leptin and insulin is a key event in the development of obesity and impaired glucose homeostasis and systemic immune responses (Belgardt \& Bruning 2010, Tschop et al. 2010, Vogt \& Bruning 2013). Both hormones act on hypothalamic neurons to decrease food intake and hepatic glucose production and to increase energy expenditure (Obici et al. 2002, Belgardt \& Bruning 2010). Two neuronal populations, each characterized by the expression of specific neuropeptides, have potent effects on energy homeostasis (Contreras et al. 2015, Lopez \& Tena-Sempere 2015). One population consists of the POMC and CART neurons, which provide a strong anorexigenic effect, decreasing food intake and body weight. In contrast, the second population of AgRP and NPY neurons has a potent orexigenic effect, increasing food intake. Since the first evidence demonstrating that brain-specific deletion of insulin receptor (InsR) was associated with diet-sensitive obesity (Bruning et al. 2000), many reports have tried to identify the neurons and mechanism by which this hormone affects the brain. In this context, the failure of conditional depletion of JNK1 in several peripheral insulin-sensitive tissues to recapitulate the phenotype of whole-body JNK1 knockout mice (Sabio et al. 2008, 2009, $2010 a, b)$ suggests the possibility that JNK1 activation in the CNS might contribute to the maintenance of energy balance and glucose metabolism. JNK activation in hypothalamus during obesity has been linked to endoplasmic reticulum stress, inflammation, and hyperlipidaemia (Ozcan et al. 2004, Prada et al. 2005). In 2010, two groups independently generated two brainspecific conditional JNK1 knockout models (Belgardt et al. 2010, Sabio et al. 2010b) using the Nestin-cre system, which is used to ablate a gene of interest in neurons and astrocytes in the CNS (Tronche et al. 1999). Both studies showed that these mice are protected against HFD-induced obesity, insulin resistance and glucose intolerance at the central and peripheral level (Belgardt et al. 2010, Sabio et al. 2010b). Reduced body-weight gain correlated with increased energy expenditure and locomotor activity and a higher body temperature

Published by Bioscientifica Ltd. 
(Belgardt et al. 2010, Sabio et al. 2010b). Moreover, the mice had depressed lipid accumulation in brown fat and elevated plasma levels of $\mathrm{T}_{3}$ and $\mathrm{T}_{4}$ thyroid hormones, which correlated with high levels of thyrotropin-releasing hormone (TRH) in hypothalamus. These data indicate that JNK1 in CNS controls body homeostasis by regulating the hypothalamic-pituitary-adrenal axis (Belgardt et al. 2010, Sabio et al. 2010b). Two newly generated mouse models are helping to further clarify the role of JNK1 in the CNS: deletion of JNK1 and JNK2 in pituitary gland and conditional overexpression of constitutively active JNK in AgRP neurons (Vernia et al. 2013, Tsaousidou et al. 2014). Vernia et al. found that lack of JNK1 and 2 in the anterior pituitary gland protects against weight gain during obesity and diabetes. Moreover, these mice have elevated energy expenditure and circulating levels of $\mathrm{T}_{3}, \mathrm{~T}_{4}$ and thyroid stimulating hormone (TSH). The study shows that JNK1/2 regulate expression of Dio2, which encodes the enzyme responsible for $T_{4}$ to $T_{3}$ conversion in the pituitary gland. Impairment of this conversion reduces the negative feedback regulation of the expression of TSH, resulting in sustained production of TSH, $\mathrm{T}_{3}$ and $\mathrm{T}_{4}$ (Vernia et al. 2013). In the second model, mice expressing constitutively active JNK1 in AgRP neurons become obese when fed a HFD and are leptin resistant at the neuronal and systemic level (Tsaousidou et al. 2014). These results indicate that JNKs, in particular JNK1, play a pivotal role in central nervous control of obesity. Further efforts are needed to address the role of JNK3, a mainly CNS isoform, in metabolism and energy homeostasis.

\section{p38 MAPK}

The four p38 MAPK isoforms $-\alpha, \beta, \gamma, \delta-$ are encoded by different genes and have different tissue expression patterns (Sabio \& Davis 2014). The p38 $\alpha$ isoform is widely expressed, but is less abundant in the brain, where p38 $\beta$ MAPK is the major isoform (Beardmore et al. 2005). The p38 $\delta$ isoform is highly expressed in a limited number of tissues, including neutrophils and endocrine glands (Sumara et al. 2009, Cuadrado \& Nebreda 2010, Ittner et al. 2012, Gonzalez-Teran et al. 2013), while p38 $\gamma$ kinase is expressed in all tissues, with high levels found in muscle (Beardmore et al. 2005).

All p38 isoforms are activated, in response to appropriate stimuli, by dual phosphorylation in the activation loop sequence Thr-Gly-Tyr. p38 MAPKs can be activated by MKK3, MKK4 or MKK6 in cell-free systems, but their activation in intact cells is primarily mediated by
MKK3 and MKK6 (Enslen et al. 2000, Brancho et al. 2003, Remy et al. 2010). However, most of these studies were performed in immortalized fibroblasts and how specific p38 MAPK isoforms are activated in response to different stimuli in other cells types is largely unknown. The function of $\mathrm{p} 38 \alpha$ has been studied in several physiological processes, and although no specific role for this kinase has been defined in metabolism, p38 $\alpha$ is known to phosphorylate several key proteins involved in glucose and lipid metabolism (Fig. 3).

\section{Liver}

Although the specific role of the different p38 isoforms in liver metabolism has not been studied, several p38 MAPK substrates have been implicated in metabolic processes. Here we summarize these substrates and current knowledge about the potential action of p38 isoforms in liver metabolism. Downstream targets of p38 include two important transcription factors involved in gluconeogenesis: transcriptional PPAR gamma coactivator-1 alpha (PGC1 $\alpha$ ) and CREB. Upon phosphorylation, PGC1 $\alpha$ and CREB activities are enhanced, and they bind to sites in the promoter regions of the genes encoding phosphoenolpyruvate carboxykinase kinase (PEPCK) and glucose-6 phosphatase, activating transcription of these gluconeogenic genes (Deak et al. 1998, Puigserver et al. 2001, Cao et al. 2005). Experiments with pharmacological inhibitors and p38-targeting shRNA have suggested that p38 might modulate gluconeogenesis via this mechanism (Cao et al. 2005). PGC1 $\alpha$ also co-activates many other transcription factors, including PPAR $\alpha$ and FOXO1. Furthermore, p38 has been proposed to directly phosphorylate PPAR $\alpha$, enhancing its activity (Juge-Aubry et al. 1999). p38 also phosphorylates CCAAT-enhancer-binding protein alpha (C/EBP $\alpha$ ) (Qiao et al. 2006), a transcription factor that regulates glucose homeostasis (Yang et al. 2005). Phosphorylation on serine enhances $\mathrm{C} / \mathrm{EBP} \alpha$ transactivation activity and increases PEPCK gene expression (Qiao et al. 2006). A more recent study showed that p38 phosphorylates the spliced form of X-box binding protein 1 (Xbp1s), promoting its nuclear translocation, reducing endoplasmic reticulum stress, and improving glycaemia during obesity (Lee et al. 2011). All these studies point to a potentially important role of p38 kinases as regulators of glucose homeostasis in the liver. However, extensive research in conditional knockout and transgenic mouse models will be needed to define the function of each p38 isoform in liver homeostasis.

Published by Bioscientifica Ltd. 

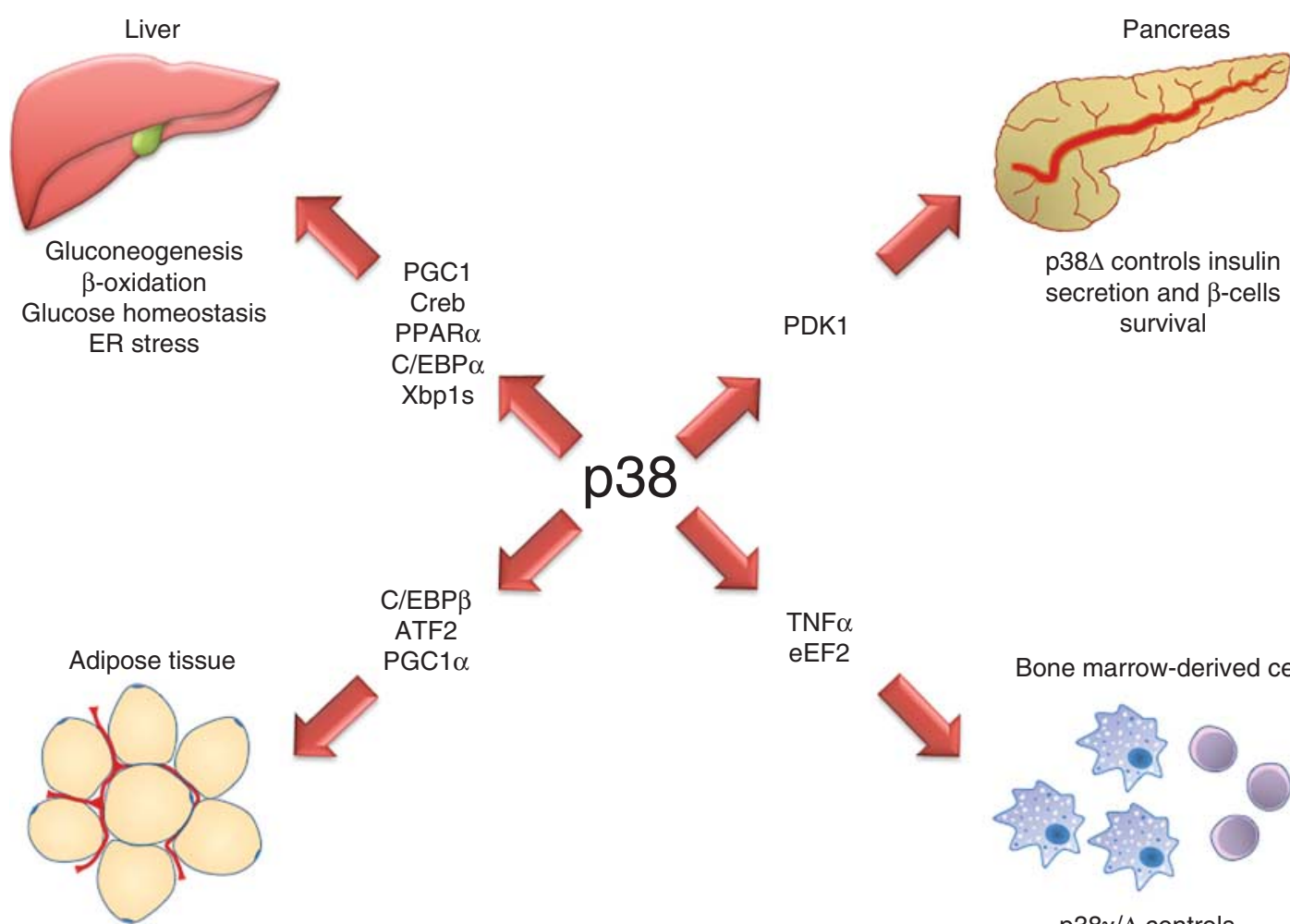

White and brown

adipose tissue differentiation

PDK1 survival

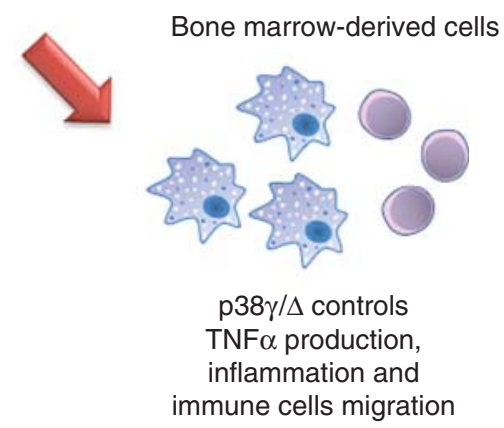

Figure 3

Roles of p38 isoforms in metabolism. p38 targets include several proteins with a prominent role in metabolism regulation, such as TNF $\alpha$, C/EBP $\beta$, and PPAR $\alpha$, suggesting a role for these SAPKs in metabolism and metabolic

\section{Adipose tissue}

Adipose tissue formation depends on tight regulation of cell growth, proliferation and differentiation (Gehart et al. 2010). It has been proposed that p38 might modulate adipocyte differentiation through the phosphorylation of C/EBPß (Engelman et al. 1998), a key transcription factor for adipose tissue differentiation (Tanaka et al. 1997). In vitro experiments with $\mathrm{p} 38 \alpha / \beta$ inhibitors have shown that p38 phosphorylates and activates $\mathrm{C} / \mathrm{EBP} \beta$, enhancing PPAR $\gamma$ transcription and promoting adipocyte differentiation. It also has been postulated that p38 $\alpha$ regulates brown adipose tissue differentiation by controlling uncoupling protein 1 (UCP1) expression levels through the phosphorylation of the transcription factors ATF2 and PGC1 $\alpha$ (Cao et al. 2004, Tseng et al. 2008). However, more experimental work is needed in knockout and conditionally deficient animals in order to define the role of p38 MAPK in adipose tissue in vivo. disease. Further studies in tissue-specific knockout mouse models are needed to clarify the specific roles of each p38 isoform.

\section{Pancreatic $\beta$ cells}

Although it has been speculated that p38 $\alpha$ might promote $\beta$ cell failure, a part from in vitro inhibitor studies, there are only a few supporting evidences (Gehart et al. 2010). A very elegant recent study showed that p38 controls insulin secretion through the phosphorylation and inhibition of polycystic kidney disease 1 protein (PKD1) (Sumara et al. 2009). PKD1 regulates insulin secretion and cell survival, and mice lacking p38 $\delta$ are protected against stress-induced $\beta$ cell death and have elevated insulin secretion.

\section{Bone-marrow-derived cells}

The p38 MAPK family regulates TNF $\alpha$ levels, a key cytokine in the control of systemic inflammation. While p38 $\alpha$ regulates $T N F \alpha$ expression by controlling its transcription and mRNA stability (Campbell et al. 2004,

Published by Bioscientifica Ltd. 
Kang et al. 2008), recent studies demonstrate key roles for p38 $\gamma$ and p38ס in the posttranscriptional regulation of $\mathrm{TNF} \alpha$ biosynthesis, with myeloid-specific $\mathrm{p} 38 \gamma / \delta$ gene ablation triggering defects in TNF $\alpha$ production (Risco et al. 2012, Gonzalez-Teran et al. 2013). Translational elongation of nascent pro-TNF $\alpha$ protein is mediated by eukaryotic elongation factor 2 (eEF2) kinase (GonzalezTeran et al. 2013), which is inhibited by p38 $\gamma / \delta$-mediated phosphorylation (Knebel et al. 2001). Neutrophils are an important cell type that triggers inflammation and monocyte migration (Nathan 2006) and that makes an important contribution to liver steatosis development and metabolic dysfunction (Talukdar et al. 2012, Bertola et al. 2013, Mansuy-Aubert et al. 2013). p38 $\gamma / \delta$ have also been shown to control their recruitment and mobility (Ittner et al. 2012, Gonzalez-Teran et al. 2013). However, the specific contribution of these kinases to chronic inflammation induced by metabolic disease has not been tested.

\section{Conclusions}

Several reports have demonstrated that SAPKs control several metabolic events and their excessive activation is associated with deleterious effects during obesity. Most of these studies have examined JNK family members, in particular the isoforms JNK1 and JNK2. Further research is needed to clarify the function of the different $\mathrm{p} 38$ isoforms during obesity and in metabolic regulation and to define the cell types in which these kinases perform their function. The functions of $\mathrm{p} 38 \gamma / \delta$ have not been studied extensively in vivo, and very little is known about their substrates and functions. Recent reports suggest that the four isoforms of p38 have widely differing functions (Sumara et al. 2009, Gehart et al. 2010, Sabio et al. 2010b, Ittner et al. 2012, Gonzalez-Teran et al. 2013, Sabio \& Davis 2014). Studies in knockout and conditionally deficient mouse models for each p38 kinase are needed in order to define the role of these proteins in health and disease.

\section{Declaration of interest}

The authors declare that there is no conflict of interest that could be perceived as prejudicing the impartiality of the review.

\section{Funding}

G S is investigator of the Ramón y Cajal Program and recipient of a Principe de Girona award. E M is a fellow of the Caixa program. This work was funded by the following grants to G S: ERC 260464, EFSD 2030, MICINN SAF2013-43506-R and Comunidad de Madrid S2010/BMD-2326. The Centro
Nacional de Investigaciones Cardiovasculares (CNIC) is supported by the Spanish Ministry of Economy and Competitiveness and the Pro-CNIC Foundation.

\section{Acknowledgements}

We thank S Bartlett for English editing.

\section{References}

Aguirre V, Uchida T, Yenush L, Davis R \& White MF 2000 The c-Jun NH(2)terminal kinase promotes insulin resistance during association with insulin receptor substrate-1 and phosphorylation of Ser(307). Journal of Biological Chemistry 275 9047-9054. (doi:10.1074/jbc.275.12.9047)

Beardmore VA, Hinton HJ, Eftychi C, Apostolaki M, Armaka M, Darragh J, McIlrath J, Carr JM, Armit LJ, Clacher C et al. 2005 Generation and characterization of p38 $\beta$ (MAPK11) gene-targeted mice. Molecular and Cellular Biology 25 10454-10464. (doi:10.1128/MCB.25.23.1045410464.2005)

Belgardt BF \& Bruning JC 2010 CNS leptin and insulin action in the control of energy homeostasis. Annals of the New York Academy of Sciences 1212 97-113. (doi:10.1111/j.1749-6632.2010.05799.x)

Belgardt BF, Mauer J, Wunderlich FT, Ernst MB, Pal M, Spohn G, Bronneke HS, Brodesser S, Hampel B, Schauss AC et al. 2010 Hypothalamic and pituitary c-Jun N-terminal kinase 1 signaling coordinately regulates glucose metabolism. PNAS 107 6028-6033. (doi:10.1073/pnas.1001796107)

Bertola A, Park O \& Gao B 2013 Chronic plus binge ethanol feeding synergistically induces neutrophil infiltration and liver injury in mice: a critical role for E-selectin. Hepatology 58 1814-1823. (doi:10.1002/ hep.26419)

Bogoyevitch MA \& Kobe B 2006 Uses for JNK: the many and varied substrates of the c-Jun N-terminal kinases. Microbiology and Molecular Biology Reviews 70 1061-1095. (doi:10.1128/MMBR.00025-06)

Brancho D, Tanaka N, Jaeschke A, Ventura JJ, Kelkar N, Tanaka Y, Kyuuma M, Takeshita T, Flavell RA \& Davis RJ 2003 Mechanism of p38 MAP kinase activation in vivo. Genes and Development 17 1969-1978. (doi:10.1101/gad.1107303)

Bruning JC, Gautam D, Burks DJ, Gillette J, Schubert M, Orban PC, Klein R, Krone W, Muller-Wieland D \& Kahn CR 2000 Role of brain insulin receptor in control of body weight and reproduction. Science $\mathbf{2 8 9}$ 2122-2125. (doi:10.1126/science.289.5487.2122)

Campbell J, Ciesielski CJ, Hunt AE, Horwood NJ, Beech JT, Hayes LA, Denys A, Feldmann M, Brennan FM \& Foxwell BM 2004 A novel mechanism for TNF $\alpha$ regulation by p38 MAPK: involvement of NF- $\kappa \mathrm{B}$ with implications for therapy in rheumatoid arthritis. Journal of Immunology 173 6928-6937. (doi:10.4049/jimmunol.173.11.6928)

Cao W, Daniel KW, Robidoux J, Puigserver P, Medvedev AV, Bai X, Floering LM, Spiegelman BM \& Collins S 2004 p38 mitogen-activated protein kinase is the central regulator of cyclic AMP-dependent transcription of the brown fat uncoupling protein 1 gene. Molecular and Cellular Biology 24 3057-3067. (doi:10.1128/MCB.24.7.30573067.2004)

Cao W, Collins QF, Becker TC, Robidoux J, Lupo EG Jr, Xiong Y, Daniel KW, Floering L \& Collins S 2005 p38 mitogen-activated protein kinase plays a stimulatory role in hepatic gluconeogenesis. Journal of Biological Chemistry 280 42731-42737. (doi:10.1074/jbc.M506223200)

Chang L \& Karin M 2001 Mammalian MAP kinase signalling cascades. Nature 410 37-40. (doi:10.1038/35065000)

Chung J, Nguyen AK, Henstridge DC, Holmes AG, Chan MH, Mesa JL Lancaster GI, Southgate RJ, Bruce CR, Duffy SJ et al. 2008 HSP72 protects against obesity-induced insulin resistance. PNAS $\mathbf{1 0 5}$ 1739-1744. (doi:10.1073/pnas.0705799105) 
Contreras C, Gonzalez F, Ferno J, Dieguez C, Rahmouni K, Nogueiras R \& Lopez M 2015 The brain and brown fat. Annals of Medicine 47 150-168. (doi:10.3109/07853890.2014.919727)

Cuadrado A \& Nebreda AR 2010 Mechanisms and functions of p38 MAPK signalling. Biochemical Journal 429 403-417. (doi:10.1042/BJ20100323)

Czaja MJ 2010 JNK regulation of hepatic manifestations of the metabolic syndrome. Trends in Endocrinology and Metabolism 21 707-713. (doi:10.1016/j.tem.2010.08.010)

Davis RJ 2000 Signal transduction by the JNK group of MAP kinases. Cell 103 239-252. (doi:10.1016/S0092-8674(00)00116-1)

Deak M, Clifton AD, Lucocq LM \& Alessi DR 1998 Mitogen- and stressactivated protein kinase-1 (MSK1) is directly activated by MAPK and SAPK2/p38, and may mediate activation of CREB. EMBO Journal 17 4426-4441. (doi:10.1093/emboj/17.15.4426)

Engelman JA, Lisanti MP \& Scherer PE 1998 Specific inhibitors of p38 mitogen-activated protein kinase block 3T3-L1 adipogenesis. Journal of Biological Chemistry 273 32111-32120. (doi:10.1074/jbc.273.48.32111)

Enslen H, Brancho DM \& Davis RJ 2000 Molecular determinants that mediate selective activation of p38 MAP kinase isoforms. EMBO Journal 19 1301-1311. (doi:10.1093/emboj/19.6.1301)

Ferrante AW Jr 2013 The immune cells in adipose tissue. Diabetes, Obesity \& Metabolism 15 (Suppl 3) 34-38. (doi:10.1111/dom.12154)

Gavrilova O, Marcus-Samuels B, Graham D, Kim JK, Shulman GI, Castle AL, Vinson C, Eckhaus M \& Reitman ML 2000 Surgical implantation of adipose tissue reverses diabetes in lipoatrophic mice. Journal of Clinical Investigation 105 271-278. (doi:10.1172/JCI7901)

Gehart H, Kumpf S, Ittner A \& Ricci R 2010 MAPK signalling in cellular metabolism: stress or wellness? EMBO Reports 11 834-840. (doi:10.1038/embor.2010.160)

Gonzalez-Teran B, Cortes JR, Manieri E, Matesanz N, Verdugo A, Rodriguez ME, Gonzalez-Rodriguez A, Valverde AM, Martin P, Davis RJ et al. 2013 Eukaryotic elongation factor 2 controls TNF $\alpha$ translation in LPS-induced hepatitis. Journal of Clinical Investigation 123 164-178. (doi:10.1172/JCI65124)

Gupta S, Barrett T, Whitmarsh AJ, Cavanagh J, Sluss HK, Derijard B \& Davis RJ 1996 Selective interaction of JNK protein kinase isoforms with transcription factors. EMBO Journal 15 2760-2770.

Haefliger JA, Tawadros T, Meylan L, Gurun SL, Roehrich ME, Martin D, Thorens B \& Waeber G 2003 The scaffold protein IB1/JIP-1 is a critical mediator of cytokine-induced apoptosis in pancreatic $\beta$ cells. Journal of Cell Science 116 1463-1469. (doi:10.1242/jcs.00356)

Han MS, Jung DY, Morel C, Lakhani SA, Kim JK, Flavell RA \& Davis RJ 2013 JNK expression by macrophages promotes obesity-induced insulin resistance and inflammation. Science 339 218-222. (doi:10.1126/ science.1227568)

Haslam DW \& James WP 2005 Obesity. Lancet 366 1197-1209. (doi:10.1016/S0140-6736(05)67483-1)

Hirosumi J, Tuncman G, Chang L, Gorgun CZ, Uysal KT, Maeda K, Karin M \& Hotamisligil GS 2002 A central role for JNK in obesity and insulin resistance. Nature 420 333-336. (doi:10.1038/nature01137)

Hotamisligil GS 2006 Inflammation and metabolic disorders. Nature $\mathbf{4 4 4}$ 860-867. (doi:10.1038/nature05485)

Hotamisligil GS, Shargill NS \& Spiegelman BM 1993 Adipose expression of tumor necrosis factor- $\alpha$ : direct role in obesity-linked insulin resistance. Science 259 87-91. (doi:10.1126/science.7678183)

Hotamisligil GS, Johnson RS, Distel RJ, Ellis R, Papaioannou VE \& Spiegelman BM 1996a Uncoupling of obesity from insulin resistance through a targeted mutation in aP2, the adipocyte fatty acid binding protein. Science 274 1377-1379. (doi:10.1126/science.274.5291.1377)

Hotamisligil GS, Peraldi P, Budavari A, Ellis R, White MF \& Spiegelman BM $1996 b$ IRS-1-mediated inhibition of insulin receptor tyrosine kinase activity in TNF $\alpha$ - and obesity-induced insulin resistance. Science $\mathbf{2 7 1}$ 665-668. (doi:10.1126/science.271.5249.665)

Imbernon M, Beiroa D, Vazquez MJ, Morgan DA, Veyrat-Durebex C, Porteiro B, Diaz-Arteaga A, Senra A, Busquets S, Velasquez DA et al. 2013 Central melanin-concentrating hormone influences liver and adipose metabolism via specific hypothalamic nuclei and efferent autonomic/JNK1 pathways. Gastroenterology 144 636-649. (doi:10.1053/ j.gastro.2012.10.051)

Ittner A, Block H, Reichel CA, Varjosalo M, Gehart H, Sumara G, Gstaiger M, Krombach F, Zarbock A \& Ricci R 2012 Regulation of PTEN activity by p388-PKD1 signaling in neutrophils confers inflammatory responses in the lung. Journal of Experimental Medicine 209 2229-2246. (doi:10.1084/ jem.20120677)

Jaeschke A, Czech MP \& Davis RJ 2004 An essential role of the JIP1 scaffold protein for JNK activation in adipose tissue. Genes and Development 18 1976-1980. (doi:10.1101/gad.1216504)

Jaeschke A, Rincon M, Doran B, Reilly J, Neuberg D, Greiner DL, Shultz LD, Rossini AA, Flavell RA \& Davis RJ 2005 Disruption of the Jnk2 (Mapk9) gene reduces destructive insulitis and diabetes in a mouse model of type I diabetes. PNAS 102 6931-6935. (doi:10.1073/pnas.0502143102)

Jonas JC, Sharma A, Hasenkamp W, Ilkova H, Patane G, Laybutt R, BonnerWeir S \& Weir GC 1999 Chronic hyperglycemia triggers loss of pancreatic $\beta$ cell differentiation in an animal model of diabetes. Journal of Biological Chemistry 274 14112-14121. (doi:10.1074/jbc.274. 20.14112)

Juge-Aubry CE, Hammar E, Siegrist-Kaiser C, Pernin A, Takeshita A, Chin WW, Burger AG \& Meier CA 1999 Regulation of the transcriptional activity of the peroxisome proliferator-activated receptor $\alpha$ by phosphorylation of a ligand-independent trans-activating domain. Journal of Biological Chemistry 274 10505-10510. (doi:10.1074/jbc.274. 15.10505)

Kaneto H, Xu G, Fujii N, Kim S, Bonner-Weir S \& Weir GC 2002 Involvement of c-Jun N-terminal kinase in oxidative stress-mediated suppression of insulin gene expression. Journal of Biological Chemistry 277 30010-30018. (doi:10.1074/jbc.M202066200)

Kaneto H, Nakatani Y, Kawamori D, Miyatsuka T, Matsuoka TA, Matsuhisa M \& Yamasaki Y 2005 Role of oxidative stress, endoplasmic reticulum stress, and c-Jun $\mathrm{N}$-terminal kinase in pancreatic $\beta$-cell dysfunction and insulin resistance. International Journal of Biochemistry \& Cell Biology 37 1595-1608. (doi:10.1016/j.biocel.2005.04.003)

Kang YJ, Chen J, Otsuka M, Mols J, Ren S, Wang Y \& Han J 2008 Macrophage deletion of $\mathrm{p} 38 \alpha$ partially impairs lipopolysaccharideinduced cellular activation. Journal of Immunology 180 5075-5082. (doi:10.4049/jimmunol.180.7.5075)

Kim HJ, Higashimori T, Park SY, Choi H, Dong J, Kim YJ, Noh HL, Cho YR, Cline G, Kim YB et al. 2004a Differential effects of interleukin-6 and -10 on skeletal muscle and liver insulin action in vivo. Diabetes $\mathbf{5 3}$ 1060-1067. (doi:10.2337/diabetes.53.4.1060)

Kim JK, Gimeno RE, Higashimori T, Kim HJ, Choi H, Punreddy S, Mozell RL, Tan G, Stricker-Krongrad A, Hirsch DJ et al. 2004b Inactivation of fatty acid transport protein 1 prevents fat-induced insulin resistance in skeletal muscle. Journal of Clinical Investigation 113 756-763. (doi:10.1172/JCI200418917)

Klover PJ, Zimmers TA, Koniaris LG \& Mooney RA 2003 Chronic exposure to interleukin-6 causes hepatic insulin resistance in mice. Diabetes $\mathbf{5 2}$ 2784-2789. (doi:10.2337/diabetes.52.11.2784)

Knebel A, Morrice N \& Cohen P 2001 A novel method to identify protein kinase substrates: eEF2 kinase is phosphorylated and inhibited by SAPK4/p38ס. EMBO Journal 20 4360-4369. (doi:10.1093/emboj/ 20.16.4360)

Lanthier N, Molendi-Coste O, Horsmans Y, van Rooijen N, Cani PD \& Leclercq IA 2010 Kupffer cell activation is a causal factor for hepatic insulin resistance. American Journal of Physiology. Gastrointestinal and Liver Physiology 298 G107-G116. (doi:10.1152/ajpgi.00391.2009)

Lanuza-Masdeu J, Arevalo MI, Vila C, Barbera A, Gomis R \& Caelles C 2013 In vivo JNK activation in pancreatic $\beta$-cells leads to glucose intolerance caused by insulin resistance in pancreas. Diabetes 62 2308-2317. (doi:10.2337/db12-1097)

Lee J, Sun C, Zhou Y, Lee J, Gokalp D, Herrema H, Park SW, Davis RJ \& Ozcan U 2011 p38 MAPK-mediated regulation of Xbp1s is crucial for 
glucose homeostasis. Nature Medicine 17 1251-1260. (doi:10.1038/ $\mathrm{nm} .2449)$

Lopez M \& Tena-Sempere M 2015 Estrogens and the control of energy homeostasis: a brain perspective. Trends in Endocrinology and Metabolism 26 411-421. (doi:10.1016/j.tem.2015.06.003)

Mansuy-Aubert V, Zhou QL, Xie X, Gong Z, Huang JY, Khan AR, Aubert G, Candelaria K, Thomas S, Shin DJ et al. 2013 Imbalance between neutrophil elastase and its inhibitor $\alpha 1$-antitrypsin in obesity alters insulin sensitivity, inflammation, and energy expenditure. Cell Metabolism 17 534-548. (doi:10.1016/j.cmet.2013.03.005)

Nakatani Y, Kaneto H, Kawamori D, Hatazaki M, Miyatsuka T, Matsuoka TA, Kajimoto Y, Matsuhisa M, Yamasaki Y \& Hori M 2004 Modulation of the JNK pathway in liver affects insulin resistance status. Journal of Biological Chemistry 279 45803-45809. (doi:10.1074/jbc.M406963200)

Nathan C 2006 Neutrophils and immunity: challenges and opportunities. Nature Reviews. Immunology 6 173-182. (doi:10.1038/nri1785)

Neels JG \& Olefsky JM 2006 Inflamed fat: what starts the fire? Journal of Clinical Investigation 116 33-35. (doi:10.1172/JCI27280)

Obici S, Feng Z, Karkanias G, Baskin DG \& Rossetti L 2002 Decreasing hypothalamic insulin receptors causes hyperphagia and insulin resistance in rats. Nature Neuroscience 5 566-572. (doi:10.1038/ nn0602-861)

Ozcan U, Cao Q, Yilmaz E, Lee AH, Iwakoshi NN, Ozdelen E, Tuncman G, Gorgun C, Glimcher LH \& Hotamisligil GS 2004 Endoplasmic reticulum stress links obesity, insulin action, and type 2 diabetes. Science 306 457-461. (doi:10.1126/science.1103160)

Paul A, Wilson S, Belham CM, Robinson CJ, Scott PH, Gould GW \& Plevin R 1997 Stress-activated protein kinases: activation, regulation and function. Cellular Signalling 9 403-410. (doi:10.1016/S08986568(97)00042-9)

Pirianov G, Brywe KG, Mallard C, Edwards AD, Flavell RA, Hagberg H \& Mehmet H 2007 Deletion of the c-Jun N-terminal kinase 3 gene protects neonatal mice against cerebral hypoxic-ischaemic injury. Journal of Cerebral Blood Flow and Metabolism 27 1022-1032. (doi:10.1038/sj. jcbfm.9600413)

Prada PO, Zecchin HG, Gasparetti AL, Torsoni MA, Ueno M, Hirata AE, Corezola do Amaral ME, Hoer NF, Boschero AC \& Saad MJ 2005 Western diet modulates insulin signaling, c-Jun N-terminal kinase activity, and insulin receptor substrate-1ser307 phosphorylation in a tissue-specific fashion. Endocrinology 146 1576-1587. (doi:10.1210/en. 2004-0767)

Puigserver P, Rhee J, Lin J, Wu Z, Yoon JC, Zhang CY, Krauss S, Mootha VK, Lowell BB \& Spiegelman BM 2001 Cytokine stimulation of energy expenditure through p38 MAP kinase activation of PPAR $\gamma$ coactivator-1. Molecular Cell 8 971-982. (doi:10.1016/S1097-2765(01)00390-2)

Qiao L, MacDougald OA \& Shao J 2006 CCAAT/enhancer-binding protein $\alpha$ mediates induction of hepatic phosphoenolpyruvate carboxykinase by p38 mitogen-activated protein kinase. Journal of Biological Chemistry 281 24390-24397. (doi:10.1074/jbc.M603038200)

Remy G, Risco AM, Inesta-Vaquera FA, Gonzalez-Teran B, Sabio G, Davis RJ \& Cuenda A 2010 Differential activation of p38MAPK isoforms by MKK6 and MKK3. Cellular Signalling 22 660-667. (doi:10.1016/j.cellsig. 2009.11.020)

Risco A, del Fresno C, Mambol A, Alsina-Beauchamp D, MacKenzie KF, Yang HT, Barber DF, Morcelle C, Arthur JS, Ley SC et al. 2012 p38 $\gamma$ and p38 kinases regulate the toll-like receptor 4 (TLR4)-induced cytokine production by controlling ERK1/2 protein kinase pathway activation. PNAS 109 11200-11205. (doi:10.1073/pnas.1207290109)

Roden M 2004 How free fatty acids inhibit glucose utilization in human skeletal muscle. News in Physiological Sciences 19 92-96.

Sabio G \& Davis RJ 2010 cJun NH2-terminal kinase 1 (JNK1): roles in metabolic regulation of insulin resistance. Trends in Biochemical Sciences 35 490-496. (doi:10.1016/j.tibs.2010.04.004)

Sabio G \& Davis RJ 2014 TNF and MAP kinase signalling pathways. Seminars in Immunology 26 237-245. (doi:10.1016/j.smim.2014.02.009)
Sabio G, Das M, Mora A, Zhang Z, Jun JY, Ko HJ, Barrett T, Kim JK \& Davis RJ 2008 A stress signaling pathway in adipose tissue regulates hepatic insulin resistance. Science 322 1539-1543. (doi:10.1126/science. 1160794)

Sabio G, Cavanagh-Kyros J, Ko HJ, Jung DY, Gray S, Jun JY, Barrett T, Mora A, Kim JK \& Davis RJ 2009 Prevention of steatosis by hepatic JNK1. Cell Metabolism 10 491-498. (doi:10.1016/j.cmet.2009.09.007)

Sabio G, Kennedy NJ, Cavanagh-Kyros J, Jung DY, Ko HJ, Ong H, Barrett T, Kim JK \& Davis RJ 2010a Role of muscle c-Jun NH2-terminal kinase 1 in obesity-induced insulin resistance. Molecular and Cellular Biology 30 106-115. (doi:10.1128/MCB.01162-09)

Sabio G, Cavanagh-Kyros J, Barrett T, Jung DY, Ko HJ, Ong H, Morel C, Mora A, Reilly J, Kim JK et al. 2010b Role of the hypothalamicpituitary-thyroid axis in metabolic regulation by JNK1. Genes and Development 24 256-264. (doi:10.1101/gad.1878510)

Schattenberg JM, Singh R, Wang Y, Lefkowitch JH, Rigoli RM, Scherer PE \& Czaja MJ 2006 JNK1 but not JNK2 promotes the development of steatohepatitis in mice. Hepatology 43 163-172. (doi:10.1002/hep. 20999)

Shulman GI 2000 Cellular mechanisms of insulin resistance. Journal of Clinical Investigation 106 171-176. (doi:10.1172/JCI10583)

Singh R, Wang Y, Xiang Y, Tanaka KE, Gaarde WA \& Czaja MJ 2009 Differential effects of JNK1 and JNK2 inhibition on murine steatohepatitis and insulin resistance. Hepatology 49 87-96. (doi:10.1002/ hep.22578)

Solinas G, Naugler W, Galimi F, Lee MS \& Karin M 2006 Saturated fatty acids inhibit induction of insulin gene transcription by JNK-mediated phosphorylation of insulin-receptor substrates. PNAS 103 16454-16459. (doi:10.1073/pnas.0607626103)

Solinas G, Vilcu C, Neels JG, Bandyopadhyay GK, Luo JL, Naugler W, Grivennikov S, Wynshaw-Boris A, Scadeng M, Olefsky JM et al. 2007 JNK1 in hematopoietically derived cells contributes to diet-induced inflammation and insulin resistance without affecting obesity. Cell Metabolism 6 386-397. (doi:10.1016/j.cmet.2007.09.011)

Speakman JR 2010 FTO effect on energy demand versus food intake. Nature 464 E1 discussion E2. (doi:10.1038/nature08807)

Standen CL, Kennedy NJ, Flavell RA \& Davis RJ 2009 Signal transduction cross talk mediated by Jun N-terminal kinase-interacting protein and insulin receptor substrate scaffold protein complexes. Molecular and Cellular Biology 29 4831-4840. (doi:10.1128/MCB.00155-09)

Sumara G, Formentini I, Collins S, Sumara I, Windak R, Bodenmiller B, Ramracheya R, Caille D, Jiang H, Platt KA et al. 2009 Regulation of PKD by the MAPK p38 in insulin secretion and glucose homeostasis. Cell 136 235-248. (doi:10.1016/j.cell.2008.11.018)

Talukdar S, Oh da Y, Bandyopadhyay G, Li D, Xu J, McNelis J, Lu M, Li P, Yan Q, Zhu Y et al. 2012 Neutrophils mediate insulin resistance in mice fed a high-fat diet through secreted elastase. Nature Medicine $\mathbf{1 8}$ 1407-1412. (doi:10.1038/nm.2885)

Tanaka T, Yoshida N, Kishimoto T \& Akira S 1997 Defective adipocyte differentiation in mice lacking the C/EBP $\beta$ and/or C/EBP $\delta$ gene. EMBO Journal 16 7432-7443. (doi:10.1093/emboj/16.24.7432)

Tronche F, Kellendonk C, Kretz O, Gass P, Anlag K, Orban PC, Bock R, Klein R \& Schutz G 1999 Disruption of the glucocorticoid receptor gene in the nervous system results in reduced anxiety. Nature Genetics 23 99-103. (doi:10.1038/12703)

Tsaousidou E, Paeger L, Belgardt BF, Pal M, Wunderlich CM, Bronneke H, Collienne U, Hampel B, Wunderlich FT, Schmidt-Supprian M et al. 2014 Distinct roles for JNK and IKK activation in agouti-related peptide neurons in the development of obesity and insulin resistance. Cell Reports 9 1495-1506. (doi:10.1016/j.celrep.2014.10.045)

Tschop J, Nogueiras R, Haas-Lockie S, Kasten KR, Castaneda TR, Huber N, Guanciale K, Perez-Tilve D, Habegger K, Ottaway N et al. 2010 CNS leptin action modulates immune response and survival in sepsis. Journal of Neuroscience 30 6036-6047. (doi:10.1523/JNEUROSCI.487509.2010) 
Tseng YH, Kokkotou E, Schulz TJ, Huang TL, Winnay JN, Taniguchi CM, Tran TT, Suzuki R, Espinoza DO, Yamamoto Y et al. 2008 New role of bone morphogenetic protein 7 in brown adipogenesis and energy expenditure. Nature $\mathbf{4 5 4}$ 1000-1004. (doi:10.1038/nature07221)

Tuncman G, Hirosumi J, Solinas G, Chang L, Karin M \& Hotamisligil GS 2006 Functional in vivo interactions between JNK1 and JNK2 isoforms in obesity and insulin resistance. PNAS 103 10741-10746. (doi:10.1073/pnas.0603509103)

Vallerie SN, Furuhashi M, Fucho R \& Hotamisligil GS 2008 A predominant role for parenchymal c-Jun amino terminal kinase (JNK) in the regulation of systemic insulin sensitivity. PLOS ONE 3 e3151. (doi:10.1371/journal.pone.0003151)

Vernia S, Cavanagh-Kyros J, Barrett T, Jung DY, Kim JK \& Davis RJ 2013 Diet-induced obesity mediated by the JNK/DIO2 signal transduction pathway. Genes and Development 27 2345-2355. (doi:10.1101/gad. 223800.113)

Vernia S, Cavanagh-Kyros J, Garcia-Haro L, Sabio G, Barrett T, Jung DY, Kim JK, Xu J, Shulha HP, Garber M et al. 2014 The PPAR $\alpha$-FGF21 hormone axis contributes to metabolic regulation by the hepatic JNK signaling pathway. Cell Metabolism 20 512-525. (doi:10.1016/j.cmet. 2014.06.010)

Vogt MC \& Bruning JC 2013 CNS insulin signaling in the control of energy homeostasis and glucose metabolism - from embryo to old age. Trends in Endocrinology and Metabolism 24 76-84. (doi:10.1016/j.tem. 2012.11.004)

Waeber G, Delplanque J, Bonny C, Mooser V, Steinmann M, Widmann C, Maillard A, Miklossy J, Dina C, Hani EH et al. 2000 The gene MAPK8IP1, encoding islet-brain-1, is a candidate for type 2 diabetes. Nature Genetics 24 291-295. (doi:10.1038/73523)
Weisberg SP, McCann D, Desai M, Rosenbaum M, Leibel RL \& Ferrante AW Jr 2003 Obesity is associated with macrophage accumulation in adipose tissue. Journal of Clinical Investigation 112 1796-1808. (doi:10.1172/ JCI200319246)

Whitmarsh AJ, Kuan CY, Kennedy NJ, Kelkar N, Haydar TF, Mordes JP, Appel M, Rossini AA, Jones SN, Flavell RA et al. 2001 Requirement of the JIP1 scaffold protein for stress-induced JNK activation. Genes and Development 15 2421-2432. (doi:10.1101/gad.922801)

Xu H, Barnes GT, Yang Q, Tan G, Yang D, Chou CJ, Sole J, Nichols A, Ross JS, Tartaglia LA et al. 2003 Chronic inflammation in fat plays a crucial role in the development of obesity-related insulin resistance. Journal of Clinical Investigation 112 1821-1830. (doi:10.1172/JCI200319451)

Yang J, Croniger CM, Lekstrom-Himes J, Zhang P, Fenyus M, Tenen DG, Darlington GJ \& Hanson RW 2005 Metabolic response of mice to a postnatal ablation of CCAAT/enhancer-binding protein $\alpha$. Journal of Biological Chemistry 280 38689-38699. (doi:10.1074/jbc. M503486200)

Yoon SO, Park DJ, Ryu JC, Ozer HG, Tep C, Shin YJ, Lim TH, Pastorino L, Kunwar AJ, Walton JC et al. 2012 JNK3 perpetuates metabolic stress induced by A $\beta$ peptides. Neuron 75 824-837. (doi:10.1016/j.neuron. 2012.06.024)

Yu C, Minemoto Y, Zhang J, Liu J, Tang F, Bui TN, Xiang J \& Lin A 2004 JNK suppresses apoptosis via phosphorylation of the proapoptotic Bcl-2 family protein BAD. Molecular Cell 13 329-340. (doi:10.1016/S10972765(04)00028-0)

Zhang X, Xu A, Chung SK, Cresser JH, Sweeney G, Wong RL, Lin A \& Lam KS 2011 Selective inactivation of c-Jun NH2-terminal kinase in adipose tissue protects against diet-induced obesity and improves insulin sensitivity in both liver and skeletal muscle in mice. Diabetes $\mathbf{6 0}$ 486-495. (doi:10.2337/db10-0650)

Received in final form 18 August 2015

Accepted 20 August 2015
(C) 2015 Society for Endocrinology Printed in Great Britain 